\title{
PENGARUH PERSEPSI TERHADAP MINAT KONSUMEN MEMBELI KARTU SELULER 3 DI KECAMATAN PAMEKASAN
}

\author{
Ummi Wahyuni \\ UNIVERSITAS MADURA
}

\begin{abstract}
Abstrak
Penelitian ini dilaksanakan untuk mengetahui pengaruh persepsi terhadap minat konsumen membeli kartu seluler 3 di Kecamatan Pamekasan.

Yang menjadi obyek pada Penelitian ini adalah masyarakat Kecamatan Kota Pamekasan . Adapun sample penelitian ini menggunakan sample sebanyak 105 responden pengambilan datanya dengan menggunakan dan menyebarkan angket selama 7 hari kerja. Adapun model penelitian yang digunakan adalah dengan menggunakan regresi linaer sederhana.

Hasil perhitungan dengan menggunakan analisa linear sederhana dapat diketahui bahwa korelai dengan nilai positif sebesar 0,716 atau $71.6 \%$. \%.

Hasil perhitungan dengan menggunakan metode regresi linear sederhana Nilai $R$ sebesar 0,716 atau $71,6 \%$ yaitu menggambarkan pengaruh antara variable bebas bersifat searah dan kuat. Nilai $R$ squared atau determinan $R$ sebesar 0,513 atau $51,3 \%$ artinya $29,7 \%$ dipengaruhi oleh faktor lain yang tidak diteliti dalam penelitian ini.

Berdasarkan hasil perhitungan diperoleh thitung untuk variabel persepsi $(X)$ sebesar 8,443 dan kalau dikonsultasikan dengan t tabel sebesar 1,98 didapat $t$ hitung $>t$ tabel maka dapat diambil kesimpulan bahwa dugaan bahwa variabel persepsi mempengaruhi minat konsumen membeli di Pamekasan dapat dibuktikan

\section{PENDAHULUAN}

Definisi marketing mix menurut America Marketing Association adalah proses merencanakan konsepsi, harga, promosi, dan distribusi ide, menciptakan peluang yang memuaskan individu dengan tujuan organisasi (Alma, 2003:3). Dengan demikian marketing mix merupakan salah satu faktor penting untuk mempengaruhi perilaku konsumen terutama dalam menciptakan persepsi konsumen. Persepsi adalah suatu proses pengorganisasian dan pemaknaan terhadap kesan-kesan

sensori untuk memberi arti pada lingkungannya.

Perkembangan industri seluler sangat pesat khususnya di Pamekasan dan Madura pada umumnya, hal ini dapat dilihat dari semakin banyaknya jenis kartu seluler yang beredar di tengah-tengah masyarakat dan bahkan hampir mencapai pelosok desa tanpa mengenal adanya tingkatan masyarakat. Dengan semakin ketatnya persaingan tersebut, masing-masing produsen kartu seluler berupaya dan berusaha untuk memberikan kepuasan dengan
\end{abstract}


membangun dan menciptakan image serta persepsi yang baik, sehinggga konsumen tertarik untuk menggunakan dan memakai kartu seluler yang merekan inginkan.

Persepsi konsumen ini sangat penting karena perilaku konsumen konsumen didasarkan oleh persepsi mereka tentang apa itu kenyataan dan bukan kenyataan itu sendiri. Dalam persepsi seseorang juga melalui proses seleksi. Seleksi adalah proses seseorang memilih dan menentukan marketing stimuli karena tiap individu adalah unik dalam kebutuhan, keinginan dan pengalaman, sikap dan karakter pribadi masing-masing orang

Kepuasan konsumen harus diutamakan, karena kepuasan konsumen memegang peranan yang sangat penting, upaya untuk mempertahankan pelanggan, dan menarik pelanggan dan calon pelanggan baru membutuhkan suatu kerja keras, biaya, dan strategi pemasaran yang baik.

Pelayanan merupakan suatu aktivitas yang diberikan kepada konsumen sehingga konsumen merasa puas, dalam upaya memberikan kepuasan kepada konsumen produsen kartu seluler 3 ) berusaha untuk memberikan layanan terbaiknya dengan menyediakan operator center yang dapat dihubungi selama 24 jam dan memberikan kemudahan kepada para pengguna untuk dapat dengan mudah menghubungi operator 3 center tanpa dikenakan beban biaya. Disamping itu untuk memberikan pelayanan terbaiknya operator kartu seluler 3 menyediakan berbagai informasi bagi para pengguna 3 dan dapat dengan mudah para pengguna untuk melakukan akses ke operator 3 center
Upaya lain yang dilakukan oleh Kartu 3 untuk dapat memberikan kepuasan kepada para pengguna atau konsumen adalah dengan memberikan harga yang terjangkau yaitu dengan menyediakan berbagai pilihan harga sesuai dengan kemampuan dari para pengguna atau konsumen 3 . Dengan harga yang murah melalui tarif per detiknya apabila melakukan percakapan langsung ke sesama kartu 3 dan SMS - an ke sesama 3 telah menempatkan kartu 3 sebagai kartu seluler yang cukup diminati oleh masyarakat, sehingga tidaklah heran kalau masyarakat Pamekasan banyak menggunakan kartu seluler 3, apa yang dilakukan oleh kartu 3 adalah upaya untuk membangun persepsi konsumen.

Sehingga persepsi adalah faktor penting untuk mempengaruhi konsumen. Dalam upaya untuk mempengaruhi konsumen tidaklah mudah, Keputusan konsumen merupakan suatu proses, dimana konsumen memutuskan untuk memilih produk dari berbagai produk yang ada atau dapat diartikan juga sebagai suatu proses dimana konsumen menentukan pilihan terhadap suatu produk.

Dari latar belakang masalah tersebut diatas maka peneliti dalam penelitian ini mengambil judul “

Pengaruh Persepsi Konsumen Terhadap Minat Konsumen Membeli Kartu Seluler 3 di Kecamatan Kota Pamekasan ".

\subsection{Rumusan Masalah}

Stonner dalam Sugiono ( 2002:35) menyebutkan bahwa" masalah dapat diartikan sebagai penyimpangan antara yang seharusnya dengan apa yang benarbenar terjadi".

Sedangkan Tuckman dalam Sugiono (2002:36) menyatakan 
bahwa " rumusan masalah yang baik adalah yang menanyakan hubungan antara dua variabel atau lebih, dinyatakan dalam bentuk kalimat tanya atau alternatif yang tetapi secara implisit mengandung pertanyaan ".

Berdasarkan latar belakang masalah tersebut, maka rumusan masalah pada penelitian ini sebagai berikut :

"Bagaimanakah pengaruh persepsi konsumen terhadap minat konsumen membeli kartu seluler 3 di Kecamatan Kota Pamekasan?.

\section{TINJAUAN PUSTAKA}

\section{Persepsi Konsumen}

Konsumen adalah setiap orang pemakai barang dan atau jasa yang tersedia dalam masyarakat, baik bagi kepentingan diri sendiri, keluarga, orang lain, maupun makhluk hidup lain dan tidak untuk diperdagangkan. Jika tujuan pembelian produk tersebut untuk dijual kembali, maka dia disebut pengecer atau distributor. Pada masa sekarang ini bukan suatu rahasia lagi bahwa sebenarnya konsumen adalah raja sebenarnya, oleh karena itu produsen yang memiliki prinsip holistic marketing sudah seharusnya memperhatikan semua yang menjadi hak-hak konsumen

Kualitas jasa merupakan sesuatu yang sering Kita terima atau rasakan mamun sebenarnya apa sih kualitas tersebut? Beberapa pakar marketing menjelaskan sebagai berikut: kualitas jasa harus dimulai dari kebutuhan konsumen dan berakhir pada persepsi konsumen tersebut. Hal ini berarti bahwa citra kualitas yang baik bukanlah berdasarkan sudut pandang pihak penyedia jasa, melainkan berdasarkan sudut pandang atau persepsi konsumen. Dalam hal ini pelanggan yang mengkonsumsi dan menikmati jasa perusahaan, sehingga merekalah yang seharusnya menentukan kualitas jasa. Persepsi konsumen terhadap kualitas jasa merupakan penilaian menyeluruh atas keunggulan suatu jasa

Menurut Robbins (1998:234), persepsi adalah suatu proses pengorganisasian dan pemaknaan terhadap kesan-kesan sensori untuk memberi arti pada lingkungannya.

Persepsi konsumen ini sangat penting dipelajari karena perilaku konsumen karena perilaku konsumen didasarkan oleh persepsi mereka tentang apa itu kenyataan dan bukan kenyataan itu sendiri. Menurut shiffman dan kanuk (1997) persepsi akan sesuatu berasal dari interaksi antara dua jenis faktor :

1. Faktor stimulus, yaitu karakteristik secara fisik seperti ukuran, berat, warna atau bentuk. Tampilan suatu produk baik kemasan maupun karakteristik akan mampu menciptakan suatu rangsangan pada indra manusian, sehingga mampu menciptakan sesuatu persepsi mengenai produk yang dilihatnya.

2. Faktor individu, yang termasuk proses didalamnya bukan hanya pada panca indra akan tetapi juga pada proses pengalaman yang serupa dan dorongan utama serta harapan dari individu itu sendiri.

Dalam persepsi seseorang juga melalui proses seleksi. Seleksi adalah proses seseorang memilih dan menentukan marketing stimuli karena tiap individu adalah unik dalam kebutuhan, keinginan dan pengalaman, sikap dan karakter pribadi masing-masing orang. Menurut Shiffman dan Kanuk (2000:78) dalam seleksi ada proses yang disebut selective perception 
concept. Adapun selective selective perception concept, yaitu :

\section{Selective Exposure}

Konsumen secara efektif mencari pesan menemukan kesenangan atau simpati mereka secara aktif menghindari kesakitan atau ancaman disisi lainnya. Mereka secara efektif membuka diri mereka kepada iklan-ikaln yang menentramkan hati mereka mengenai kebijaksanaan tentang kepuasaan pembeliannya.

\section{Selective Attention}

Konsumen mengadakan transaksi pemilihan yang bagus dengan tujuan perhatian merek berikan pada rangsangan komersial. Mereka mempunyai kesadaran tinggi terhadap rangsangan yang sesuai dengan minat dan kebutuhan mereka. Jadi konsumen mungkin untuk mengingat iklan untuk prodek yang dapat memuaskan kebutuhan mereka dan mengabaikan yang tidak mereka butuhkan.

\section{Perceptual Defense}

Konsumen secara bawah sadar menyaring rangsangan yang mereka temukan ancaman psikological, meskipun telah terdapat pembukaan. Jadi ancaman atau sebaliknya rangsangan yang merusak mungkin lebih sedikit diterima secara sadar daripada rangsangan netral pada level pembukaan yang sama.

\section{Perceptual Blocking}

Konsumen melindungi diri mereka dari rangsangan-rangsangan yang mereka anggap negatif dan mempunyai pengaruh buruk bagi diri mereka.

\section{Karateristik Seseorang Mempengaruhi persepsi}

Proses terjadinya persepsi meliputi 1) Proses Fisis, dimana objek menimbulkan stimulus, dan stimulus mengenai alat indera.2) Proses Fisiologis, stimulus yang diterima alat indera kemudian dilanjutkan oleh saraf sensoris ke otak. 3) Proses Psikologis, terjadi proses pengolahan otak, sehingga individu menyadari tentang apa yang ia terima dengan alat indera sebagai suatu akibat dari stimulus yang diterima.

\section{Dinamika Persepsi}

Stimulus mana yang akan lulus seleksi oleh seorang individu tergantung pada

1. Sifat-sifat stimulus

Stimulus pemasaran termasuk ciri-ciri produk, atribut-atributnya, rancangan kemasan, nama merek dan iklan. Faktor stimulus yang paling penting persepsi konsumen adalah:

a. Contrast, merupakan atribut yang paling kuat. Contrast menguatkan persepsi dengan menonjolkan perbedaan intensitas stimulus itu. Jadi konsumen menerima stimulus yang berhubungan dengan konteksnya. Hal ini mendasari prinsip sosok dan latar (figure and ground). Konsumen mempersepsi suatu sosok dalam konteksnya dengan latar. Prinsip sosok dan latar dalam iklan dikatakan gagal bila konsumen ingat pernah melihat iklan tersebut tetapi tidak dapat menyebabkan nama produknya

b. Closure, pengetahuan adalah kecenderungan orang untuk mengisi, secara persepsi, bagian yang hilang dari stimulus yang tidak lengkap.

c. Proximity, menurut prinsip kedekatan, benda atau artikel yang 
berdekatan satu sama lain dalam wawasan waktu maupun ruang akan di presepsi sebagai bagianbagian yang hilang yang berhubungan dari suatu pola atau konfigurasi

\section{d. Similarity, dalam suatu} konglomerasi stimulus, orang akan mempersepsi objek-objek yang kelihatan sama menjadi satu kelompok. Ada kecenderungan konsumen tidak mengelompokan produk-produk karena kemasan warna, kemasan, dan bahkan pada penempatan rak. Ukuran, warna, posisi, dan usia dari stimulus itu. Ukuran, warna, dan posisi produk dalam stimulusatau dalam hal ini iklan harus sesuai dengan positioning produk; sedangkan stimulus yang baru tentu saja akan lebih menarik perhatian dari pada yang sudah usai

\section{Expectation (harapan) konsumen}

Orang biasanya mempunyai harapan tentang apapun yang dihadapi, baik produk maupun orang. Harapan ini di bentuk dari pengalaman sebelumnya dari informasi yang dia peroleh melalui mendia masa dan dari kenalannya atau juga apa yang dia lihat, di raba dan di dengar saat itu. Itulah sebabnya pemirsa selalu disuguhi dengan preview film yang bakan ditayangkan di TV, peserta seminar selalu di beri informasi data pribadi dan pendidikan si pembicara, bahkan produkpun diberi kemasan dengan bahan, warna dan gambar tertentu. Semua itu merupakan suatu yang mengkondisikan prospek untuk membentuk expektasi. Expektasi konsumen terhadap sirup yang berwarna merah pastilah sirup dengan rasa rosen atau frambos, dan pasti bukan rasa jeruk. Sampo yang transparan membentuk expektasi tentang kemurnian dan kebersihan.

\section{Motive}

Motive adalah dorongan untuk memenuhi kebutuhan. Dalam rangka memenuhi kebutuhan ini orang lebih memperhatika sesuatu yang menurut dia dapat memenuhi kebutuhan. Orang cenderung memasukan stimulus yang cocok dengan mitifnya ke dalam persepsi. Semakin kuat kebutuhan, semakin besar kecenderungan untuk mengabaikan stimulus yang tidak ada hubungannya dengan kebutuhan itu. Orang yang membutuhkan mobil akan tertarik pada iklan-iklan mobil, informasi tentang mobil, majalah atau tabloid otomotif, dan mengabaikan iklan dan informasi yang lain. Sebaliknya, orang yang memiliki motif melindungi diri, tidak akan bergeming dengan iklan rokok semenarik apapun, tetapi dia justru sangat tertarik pada keterangan tentang kandungan nutrisi pada kemasan makanan

\section{Tinjauan tentang Perilaku Konsumen}

Menurut London and Bitta (1993:5) menyatakan bahwa" perilaku konsumen sebagai proses keputusan dan aktivitas fisik individu yang digunakan ketika mengevaluasi,memerlukan,mengguna kan,atau menentukan barang dan jasa, dapat dijelaskan sebagai berikut: Bahwa perilaku konsumen merupakan proses keputusan mental".

Pernyataan tersebut lebih menekankan pada serangkaian perilaku konsumen sebagai konsumen, pelanggan, atau konsumen akhir yang diawali dari proses keputusan dalam aktivitas pembelian barang dan jasa.

Perilaku konsumen adalah studi tentang konsumen seperti: tukar- 
menukar sesuatu nilai untuk produk dan jasa yang memuaskan kebutuhannya. Dalam mengetahui perilaku konsumen atas permintaan produk, jika pada teori klasik perilaku konsumen ditinjau melalui pendekatan utilities kurve indeferensnya, maka pada teori terbaru ini menggunakan pendekatan atribut produk yang bersangkutan misalnya: privacy, keamanan, kenyamanan sehingga konsumen mendapatkan kepuasan atas produk, akibat mengkonsumsi atribut yang ditawarkan.

$\begin{array}{ll} & \text { Konsumen membeli barang dan } \\ \text { jasa sebagai upaya untuk } & \\ \text { memuaskan } & \text { keinginan dan }\end{array}$ kebutuhannya. Salah satu tugas dari manajemen pemasaran adalah bagaimana untuk memenuhi keinginan dan kebutuhan manusia, sehingga dalam upaya untuk memenuhi kebutuhan dan keinginan manusia tersebut manajemen pemasaran perlu untuk menentukan kebutuhan dasar dari konsumen.

Beberapa faktor yang

mempengaruhi mengapa seseorang membeli suatu produk tertentu untuk memenuhi kebutuhan dan keinginannya seperti : jenis produk, faktor ekonomi, faktor sosiologis, dan faktor lain seperti motif, sikap, kepribadian. Agar program pemasaran dapat berhasil maka manajemen perlu untuk mempelajari faktor - faktor tersebut.

Konsumen merupakan sasaran utama pemasaran dari suatu perusahaan dalam memasarkan produk atau jasa. Perubahan situasi pasar yang dinamis menyebabkan pola perilaku konsumen dalam mengkonsumsi sesuatu mengalami perubahan. Tujuan pemasaran adalah memenuhi dan memuaskan kebutuhan serta keinginan pelanggan sasaran atau konsumen. Oleh karena itu seorang pemasar harus benar benar mempelajari dan memahami perilaku konsumen yang mempunyai kecenderungan sangat dinamis.
Peran pemasaran yang merupakan ujung tombak untuk melakukan komunikasi dengan konsumen dan pelanggan sehingga para pemasar perusahaan dituntut untuk selalu berupaya memahami kebutuhan, keinginan dan permintaan pasar sasaran. Untuk dapat memahami kebutuhan, keinginan dari konsumen tidaklah mudah.

\section{Kepuasan konsumen} memegang peranan yang sangat penting, upaya untuk mempertahankan pelanggan dan menarik pelanggan dan calon pelanggan baru membutuhkan suatu kerja keras, biaya, dan strategi pemasaran yang baik.Memahami perilaku konsumen dan mengenal pelanggan tidak sederhana, pelanggan mungkin menyatakan kebutuhan dan keinginan mereka namun bertindak sebaliknya. Pelanggan mungkin tidak memahami motivasi mereka yang lebih dalam. Pelanggan mungkin menanggapi pengaruh yang mengubah pikiran mereka pada menit - menit terakhir.

Tugas pemasar adalah
memahami karateristik pembeli
tersebut agar pembeli melakukan
proses keputusan pembelian yang
pada akhirnya akan memutuskan
pembelian mengenai pilihan produk,
pilihan merk, pilihan penyalur, waktu
pembelian dan jumlah pembelian.

Karateristik pembeli yang terdiri dari budaya, sosial, pribadi, dan psikologi sangat besar sekali pengaruhnya di dalam memahami serta merespon rangsangan tersebut sehingga akan menimbulkan dan menentukan proses pengambilan keputusan dalam membeli dari konsumen. Proses pengambilan keputusan konsumen dalam melakukan pembelian terhadap suatu produk berdasarkan pada tingkat analisa yang sangat mendalam dari konsumen tersebut. 


\section{Proses Pengambilan Keputusan}

( membeli )

Menurut Philip Kottler dalam

Fandi Tjiptono ( $2000: 20$ )

menyebutkan bahwa dalam

keputusan pembelian barang, konsumen sering ada lebih dari dua pihak yang terlibat dalam proses pertukaran atau pembeliannya.

Umumnya ada lima peranan yang dapat dilakukan seseorang. Pemahaman mengenai masing masing peranan ini sangat berguna dalam rangka memuaskan kebutuhan dan keinginan konsumen.

1. Inisiator (Pemrakarsa) adalah orang yang pertama kali menyadari adanya keinginan atau kebutuhan yang belum terpenuhi dan mengusulkan ide untukmembeli.

2. Influencer ( Pemberi pengaruh ) adalah orang yang akan mempengaruhi keputusan pembelian

3. Desider ( Pengambilan keputusan ) adalah orang yang menentukan keputusan pembelian.

4. Buyer ( Pembeli ) yaitu orang yang melakukan pembelian

5. User ( Pengguna ) adalah orang yang mengkonsumsi atau menggunakan barang atau jasa yang dibeli.

Pengambilan keputusan ( memilih ) yang dilakukan konsumen pada dasarnya untuk melakukan pembelian diawali oleh adanya kesadaran pemenuhan kebutuhan atau keinginan dari konsumen itu sendiri. Atas kesadaran pemenuhan kebutuhan atau keinginan itu, maka konsumen mulai mencari informasi tentang produk yang dapat memenuhi kebutuhan atau keinginannya. Dari informasi yang didapat selanjutnya konsumen akan melakukan seleksi atas macam/produk yang tersedia .

\section{Metode Penelitian}

\section{Populasi Dan Sampel}

Yang menjadi populasi dalam penelitian ini adalah masyarakat Kecamatan Kota Pamekasan yang membeli dan menggunakan kartu seluler 3

Peneliti secara sengaja memberi angket kepada sejumlah masyarakat yang kebetulan membeli dan menggunakan kartu 3 untuk dijadikan sebagai sampel. Peneliti selama selama 7 hari kerja berada di lokasi penelitian untuk mendapatkan responden yang akan dijadikan sampel sebanyak 105 responden.

\section{Teknik Analisis}

Pada penelitian ini terdiri dari dua analisis yang terdiri dari analisis kualitatif dan analisis yang bersifat kuantitatif:

1. Analisis kualitatif adalah untuk memberikan gambaran tentang obyek yang akan diteliti, dengan menggunakan skala linkert

2. Analisis kuantitatif adalah untuk memberikan gambaran tentang kondisi obyek yang diteliti berdasarkan perhitungan statistic yaitu dengan menggunakan persamaan regresi linear sederhana, menurut pendapat Djarwanto dan Pangestu (1995:309) sebagai berikut:

$$
\mathbf{Y}=\mathbf{a}+\mathbf{b}_{1} \mathbf{X}_{\mathbf{1}}
$$

$$
\text { dimana : }
$$

$\mathrm{Y}=$ variable terikat yang ditentukan oleh besarnya $X$

$X=$ variable bebas yang menentukan besarnya $Y$

$$
\begin{aligned}
& \mathrm{b}=\text { koefisien korelasi } \\
& \mathrm{a}=\text { nilai kostanta }
\end{aligned}
$$


Sedangkan untuk menguji hipotesa yaitu dengan menggunakan uji t.

1. $\mathrm{t}$ hitung $\leq \mathrm{t}$ tabel maka Ho diterima dan $\mathrm{Hi}$ ditolak, artinya variable bebas kurang menjelaskan variabel terikatnya

2. $t$ hitung $\geq t$ tabel maka Ho ditolak dan $\mathrm{Hi}$ diterima, artinya variable bebasnya dapat menjelaskan variable terikatnya.

\section{Hasil dan Pembahasan}

Responden yang berjenis kelamin laki - laki sebanyak 45 atau $43 \%$ dan yang menjadi responden wanita sebanyak 60 responden atau 57\%. Dari table tersebut menunjukkan pada saat penelitian pendahuluan dilakukan bahwa sebagian besar masyarakat yang mengisi angket yang telah disebarkan oleh peneliti sebagian besar adalah perempuan. Yang menjadi konsumen tersebut dari berbagai kalangan, anak-anak muda, remaja, dewasa dan tua serta dari berbagai lapisan masyarakat memiliki profesi dan pekerjaan yang berbeda.

\section{a. Karateristik Berdasarkan Umur responden}

Dilihat dari umur responden, ternyata responden yang menjadi pelanggan seluler 3 dari berbagai kalangan umur. Responden dalam penelitian ini yang berumur $16-20^{\text {th }}$. Sebanyak 15 orang . Responden yang berumur 21-25 th sebanyak 23 orang. Adapun responden yang berumur 26-30th sebanyak 36 orang dan responden yang berumur $31-35^{\text {th }}$ sebanyak 20 orang. Dan berdasarkan hasil angket yang telah dikumpulkan oleh peneliti responden yang berumur 36$40^{\text {th }}$ sebanyak 10 orang dan yang berumur diatas $40^{\text {th }}$ sebanyak 11 orang.

\section{b. Karateristik Berdasarkan Pendidikan Responden}

Untuk responden dengan kategori yang berpendidikan SD sebanyak 11 orang atau $10 \%$, responden yang pendidikannya SMP sebanyak 37 orang atau $35 \%$ dan responden yang berpendidikan SMU sebanyak 32 orang atau $31 \%$. Sedangkan responden yang berpendidikan S1 sebanyak 25 orang atau $24 \%$ dapat disimpulkan bahwa sebagian besar yang menjadi pengguna kartu seluler 3 pada saat penelitian ini dilakukan adalah responden yang berpendidikan SMP.

\section{c. Karateristik Berdasarkan Pekerjaan Responden}

Responden tidak bekerja yang menjadi pengguna kartu seluler 3 sebanyak 15 orang atau 14\%, sedangkan yang menjadi responden dari swasta sebanyak 60 orang atau $57 \%$ dan responden yang bekerja sebagai PNS sebanyak 30 orang atau $29 \%$.

\section{Distribusi frekuensi Jawaban Responden}

Berdasarkan hasil angket yang telah disebarkan kepada responden yaitu sebanyak 256 angket dan yang berhasil dikumpulkan sebanyak 105 angket, berdasarkan hal tersebut, maka dapat dijelaskan mengenai distribusi fekuensi jawaban responden sebagai berikut :

a. Variabel Persepsi (X) dengan indicator terdiri-dari: kesadaran, motivasi, daya tarik, pengalaman

\section{1) Kesadaran}

responden yang menjawab cukup setuju 37 orang atau 35\%, yang menjawab setuju 42 orang atau $40 \%$ dan yang menjawab sangat 
setuju sebanyak 26 orang atau $25 \%$. Dari hasil tanggapan responden ternyata sebagian besar responden mengatakan setuju, hal ini menunjukkan bahwa konsumen selalu menginginkan layanan yang terbaik dan mampu menggugah kesadaran konsumen yang akan mempengaruhi persepsi yang baik terhadap kartu seluler 3

\section{2) Motivasi}

responden yang menjawab cukup setuju 35 orang atau $33 \%$, yang menjawab setuju 40 orang atau $38 \%$ dan yang menjawab sangat setuju sebanyak 30 orang atau $29 \%$. Dari tanggapan responden tentang motivasi konsumen untuk selalu menggunakan kartu seluler 3 sebagian besar responden menyatakan setuju

Kartu seluler 3 memberikan pelayanan yang menarik agar para pengguna seluler 3 merasakan kepuasan terhadap segala layanan yang telah dinikmati oleh para konsumen. Dengan pelayanan yang menarik diharapkan para pengguna kartu seluler 3 tertarik untuk menjadi pengguna setia dan loyal. Jasa pelayanan yang menarik sebagi wujud penghargaan kepada para pengguna kartu seluler 3 agar termotivasi untuk selalu menggunakan kartu seluler 3 .

\section{3) Daya Tarik}

responden yang menjawab cukup setuju 42 orang atau $40 \%$, yang menjawab setuju 35 orang atau 33\% dan yang menjawab sangat setuju sebanyak 28 orang atau $27 \%$.

Kartu seluler 3 dapat memberikan jasa layanan yang dapat memenuhi keinginan dan kepuasan kepada para pengguna kartu seluler 3. Tercipta kepuasan dan keinginan memberikan daya tarik bagi konsumen yang lain untuk menggunakan kartu seluler 3. Daya tarik dari kartu seluler 3 berupa produk beserta layanannya yang mampu memberikan dan menciptakan kepuasan sesuai dengan keinginan para pengguna kartu seluler 3 .

\section{4) Pengalaman}

responden yang menjawab cukup setuju 39 orang atau $37,2 \%$, yang menjawab setuju 33 orang atau $31,4 \%$ dan yang menjawab sangat setuju sebanyak 33 orang atau $31,4 \%$. Dari tanggapan responden tentang pengalaman sebagian besar responden menyatakan cukup setuju. Pengalaman dari para pengguna kartu seluler 3 merupakan referensi penting untuk dijadikan rekomendasi oleh pengguna lain atau konsumen yang akan menggunakan kartu seluler 3

Para pengguna kartu seluler 3 pasti akan mencerikan kepada keluarga, sahabat, teman dan koleganya tentang produk dan layanan yang diberikan oleh kartu seluler 3. Dari cerita tentang layanan dan produk memunculkan persepsi positif dan secara tidak langsung merupakan bentuk informasi yang berharga untuk dijadikan sebagai referensi bagi para pengguna baru untuk memutuskan mendapatkan layanan dan produk dari kartu seluler 3.

b. Variabel Minat Konsumen Membeli (Y)

\section{1) Kebutuhan}

responden yang menjawab cukup setuju 34 orang atau $32,4 \%$, yang menjawab setuju 38 orang atau $36,2 \%$ dan yang menjawab sangat setuju sebanyak 33 orang atau $31,4 \%$. Dari tanggapan responden tentang kebutuhan konsumen sebagian besar responden menyatakan setuju. 
Memutuskan untuk menggunakan kartu seluler 3 berdasarkan keyakinan konsumen. Keyakinan para pengguna kartu seluler 3 muncul dari berbagai informasi tentang kartu seluler 3 , dari berbagai informasi tersebut akan dicocokkan sesuai dengan kenyataan. Keyakinan para pengguna kartu seluler 3 juga dipengaruhi oleh persepsi masyarakat tentang kartu seluler 3. Dari persepsi masyarakat akan terintegrasi dalam pikiran para pengguna kartu seluler 3 untuk membuat sebuah minat untuk menjadi para pengguna kartu seluler 3 untuk memenuhi kebutuhannya

\section{2) Mencari Informasi}

responden yang menjawab cukup setuju 35 orang atau $33,3 \%$, yang menjawab setuju 39 orang atau $37,2 \%$ dan yang menjawab sangat setuju sebanyak 31 orang atau $29,5 \%$.

\section{3) Evaluasi Informasi}

responden yang menjawab cukup setuju 33 orang atau $31,4 \%$, yang menjawab setuju 42 orang atau $40 \%$ dan yang menjawab sangat setuju sebanyak 30 orang atau $28,6 \%$.

4) Minat

responden yang menjawab cukup setuju 26 orang atau $25 \%$, yang menjawab setuju 36 orang atau $34 \%$ dan yang menjawab sangat setuju sebanyak 43 orang atau $41 \%$. Dampak dari adanya persepsi yang baik dari para pengguna kartu seluler 3 adalah adanya minat para pengguna kartu seluler 3 untuk menjdi para pengguna kartu seluler 3 . Disamping untuk mempertahankan para pengguna kartu seluler 3 , layanan yang baik sebagai upaya untuk menarik para pengguna kartu seluler 3 baru agar menjadi para pengguna kartu seluler 3 yang berpotensi dan menjadi para pengguna kartu seluler 3 tetap serta sebagai upaya untuk mempertahankan para pengguna kartu seluler 3 yang sudah ada.

5) Evaluasi Setelah Membeli responden yang menjawab tidak setuju 9 orang atau $8,6 \%$, menjawab cukup setuju 32 orang atau $30 \%$, menjawab setuju 55 orang atau $52,4 \%$ dan menjawab sangat setuju 9 orang atau $8,6 \%$

\section{Uji Validitas Dan Uji Reliabilitas}

Berdasarkan hasil perhitungan korelasi dari variabel semua variabel maka untuk mengetahui validitas dari semua variabel maka dilakukan uji validitas semua variabel yang akan diteliti. Variabel dinyatakan valid apabila koefisien korelasi $r>0,3$. Adapun hasil perhitungaan korelasi dengan menggunakan bantuan program SPSS versi 16.00 maka dapat dilihat hasil perhitungan matrik korelasi validitas sebagai berikut 
Tabel 1

Hasil Perhitungan Uji Validitas

\begin{tabular}{|c|c|c|}
\hline Variabel X & Koefisien Korelasi & Kket. \\
\hline Kesadaran & 0,553 & valid \\
\hline Motivasi & 0,575 & valid \\
\hline Daya Tarik & 0,549 & valid \\
\hline Pengalaman & 0,547 & valid \\
\hline Variabel Y & Koefisien Korelasi & Kket. \\
\hline Kebutuhan Mencari & 0,791 & valid \\
\hline Informasi Evaluasi & 0,776 & valid \\
\hline Informasi & 0,791 & valid \\
\hline Minat & 0,512 & valid \\
\hline Evaluasi & 0,512 & valid \\
\hline
\end{tabular}

Sumber data: diolah

Dari hasil uji validitas diatas, semua variabel koefisien korelasinya diatas $0,3(>0,3)$ atau valid sehingga semua variabel dapat diikutkan dalam proses selajutnya.

\section{Uji Realibilitas}

Tujuan dari uji realibilitas adalah untuk mengetahui tingkat kehandalan dari instrumen penelitian. Variabel dapat dinyatakan handal apabila koefisien alpha $>0,5$, dengan menggunakan metode Alpha Cronbach dengan menggunakan bantuan SPSS Program Versi 16.00 dapat dilihat pada tabel dibawah ini: 
Tabel 2

Hasil Uji Realibilitas

\begin{tabular}{|c|c|l|}
\hline Variabel & Koefisien Alpha & Keterangan \\
\hline Persepsi & 773 & Handal \\
Minat & 769 & Handal \\
\hline
\end{tabular}

Sumber data: diolah

Semua variabel penelitian yang terdiri-dari persepsi $(\mathrm{X})$ dan minat $(\mathrm{Y})$ mempunyai tingkat kehandalan untuk digunakan dalam penelitian karena koefisien alpha $>0,5$

Dari hasil perhitungan statistik dengan menggunakan regresi linear sederhana dengan menggunakan bantuan program SPSS for windows versi 16.00.dapat diketahui sebagai berikut:

\section{Pengaruh Antara Variabel Bebas \\ Dan Variabel Terikat}

Tabel 3

Descriptive Statistics

\begin{tabular}{|l|l|l|l|}
\hline & Mean & Std. Deviation & N \\
\hline Minat $(Y)$ & 3.8250 & .61160 & 105 \\
Persepsi $(X)$ & 3.600 & .56479 & 105 \\
\hline
\end{tabular}

Sumber data: diolah 


\section{KESIMPULAN DAN SARAN}

\section{Kesimpulan}

Berdasarkan hasil analisis dan pembahasan, maka dapat disimpulkan bahwa

a. Dari hasil analisis statistik ternyata persepsi mempengaruhi minat konsumen. Adapun besar pengaruh yang diberikan oleh variable tersebut sebesar 0,716 atau 71,6\% (kuat).

b. Model persamaan penelitian ini adalah:

$$
Y=0,196+0,175 X
$$

Nilai konstanta sebesar 1,893 hal ini berarti bahwa pada saat variabel $X$ sama dengan nol maka minta konsumen sebesar 1,893. Koefisien variabel persepsi $(X)$ sebesar 0,524 hal ini berarti bahwa bilamana variabel persepsi ditingkatkan satusatuan maka akan menaikkan minat konsumen 0,524

Persamaan ini layak digunakan untuk memprediksi $Y$ atau minat konsumen karena nilai signifikan pada ANOVA memiliki nilai 0,000 lebih kecil dari taraf signifikan 0,005 yang digunakan dalam penelitian ini.

b. Nilai uji $\mathrm{t}$ atau $\mathrm{t}$ hitung untuk persepsi sebesar 8.433. dengan probabilitas 0,00 . Sedangkan dengan menggunakan nilai $t$ table sebesar 1,98 dan tarap nyata sebesar 0,05, maka dapat diambil suatu kesimpulan dugaan persepsi berpengaruh terhadap minat konsumen dapat dibuktikan kebenarannya

\section{Saran}

Berdasarkan kesimpulan diatas, maka saran-saran dari peneliti adalah sebagai berikut: a. Berdasarkan hasil penelitian menunjukkan bahwa persepsi berpengaruh terhadap minat konsumen oleh karena itu kartu seluler 3 untuk selalu memberikan dan meningkatkan persepsi kepada konsumen kartu seluler 3

b. Kartu seluler 3 hendaknya untuk selalu memberikan informasi sesuai dengan kebutuhan konsumen untuk dapat meningkatkan persepsi terhadap konsumen.

Pada tabel discriptive statistics dapat dijelaskan bahwa rata-rata atau means dari variabel terikat yaitu minat para pengguna kartu seluler 3 sebesar 3, 8250 dimana standart deviasi sebesar 0,61160 dengan $\mathrm{N}$ atau jumlah yang diteliti sebanyak 105 responden. Artinya bahwa minat para pengguna kartu seluler 3 termasuk baik karena berada diantara nilai 3,51-4,50.

Pada tabel discrieptieve statistics tersebut diatas juga menunjukkan bahwa variabel persepsi yang terdiri-dari: kesadaran, motivasi, daya tarik dan pengalaman termasuk baik yaitu berada diantara nilai 3,51-4,50 dengan nilai ratarata 3,600 dan standart deviasi 0,56479. dengan jumlah responden yang diteliti sebanyak 105 responden. 


\section{DAFTAR PUSTAKA}

Asssael, Henry, 1987, Consumer

Behaviour and Marketing Action, Kent Publishing, Boston USA

Djaslim Saladin, Unsur - Unsur Inti Pemasaran dan Manajemen Pemasaran, CV. Mandar Maju, Bandung, 1991.

Engel,James F., Roger D. Blackwell \& Paul W. Miniard, 1994, Alih bahasa Budiyanto, Perilaku konsumen, Edisi Ke Enam,jilid I, Binarupa Aksara,Jakarta

Kartono, Kartini, 1997, dalam Husein Umar, Metodologi Penelitian, Penerbit PT. Gramedia Pustaka Utama, Jakarta.

Kotler,Philip Manajemen Pemasaran,Jilid 1 \& 2, terjemahan Teguh Hendra, Ronny Antonius Rusli, Edisi Revisi, Prenha Hindu,Jakarta,1997

Kotler,Philip, Manajemen Pemasaran, Jilid I \& II , Terjemahan Teguh Hendra, Roni Antunios Rusli, Penyunting Agus Hasan Pura Anggawijaya, Edisi Revisi, Prenha Hindu, Yogyakarta ,2000

Loudon, D.L and A.J. D. Bitta, 1993.

Consumer Behavior Concepts and Aplication, Fourt Edition, Mc Graw-Hill,Inc.Singapore

Michelli, Dena, 1996, , Strategi

Pemasaran, Edisi Pertama, Penerbit Andy Offset, Yogyakarta

Moenir dalam Sudiarto Santoso, Pengaruh Marketing Mix Terhadap Perilaku Konsumen pada Pedagang Kaki Lima di Malang, Penelitian Universitas Muhammadyah, Malang, 1992
Santoso Singgih, Buku Latihan SPSS statistic Parametrik, Alek Media Komputindo, Jakarta, 2002

Sanusi, Misbah dalam Fandy Tjiptono, Strategi Pemasaran, Edisi Pertama, Penerbit Andy Offset, Yogyakarta, 1995

Sugiono, Metode Penelitian Administradisi, Penerbit Alpha Beta, Bandung, 2001

Sutisna, Perilaku Konsumen dan Komunikasi Pemasaran, Pt. Remaja Rosdakarya, Bandung, 2001

Swasta, Bashu. dan T.Hani Handoko, Manajemen Pemasaran, Analisa Perilaku Konsumen, Edisi Pertama,BPFE,Yogyakarta, 2000

Tjiptono, Fandy, 2000, Strategi Pemasaran, Edisi Kedua, Penerbit Andy Offset, Yogyakarta

Umar, Husein, 2002, Metodologi Penelitian Aplikasi dalam Pemasaran, Penerbit PT. Gramedia Pustaka Utama, Jakarta.

Zaltman, 1979, The Demographics and Market Foregnmentation Journal Of Marketing, Illionis. 
ISSN 1412-2936 